\title{
The Latency of the Female's Cephalofacial Variables
}

\author{
Latencia de Variables Cefalofaciales en Mujeres
}

Agron M. Rexhepi: ${ }^{*, *, * * *}$ \& Behlul Brestovci, ${ }^{* * * * *}$

REXHEPI, A. M. \& BRESTOVCI, B. The latency of the female's cephalofacial variables. Int. J. Morphol., 31(2):765-770, 2013

SUMMARY: The human craniofacial bones are certainly the most important part of the body, as well as the foundation for the soft tissues of the face and head. This part of the body is extremely complex structure, which has a number of important functions, such are: diet, special senses, protection, communication. The main purpose of this research was to study and explain the latent structure of the cephalofacial measurements of female subjects. On 193 female subjects aged 18-35 years, we measured 11 cephalofacial measurements. The collected data are analyzed through descriptive parameters, Correlation analysis, and Factorial analyses. According to the results of the basic parameters the measured subjects are characterized with long, large and medium height head. Correlation analysis confirms some sets of variables that realize the higher correlations with each other. According to the principal component analysis of the Factor Analysis, with the rotation method direct oblimin, and using the Keiser criterion have been extracted four latent factors that explain 66.39 $\%$ of the total variance: The cranial factor; The factor of intracranial capacity; The transversal factor of the face; The longitudinal factor of the face. The composition of the extracted factors is compatible with the anthropological explanation of the anthropologists regarding the development of these tissues of the head.

KEY WORDS: Cephalofacial measurements; Latent structure; Anthropological explanation.

\section{INTRODUCTION}

The human skull, which forms the cranial cavity, is a unique skeletal complex structure (Enlow, 1968; Martin et al., 2001; Williams et al., 1995), as well as an excellent anatomical subsystem, whose measurements enable a chronological study of the anthropological features of the nations (Coon, 1939; Dhima, 1985; Rexhepi \& Meka, 2008; Ylli, 1975).

Craniometry is a section of anthropometry that exclusively studies the cranium, whereas cephalometry studies the head of a living subject. The cephalometrical measurements might be taken either directly (anthropometric measurements) or indirectly (radiography,MRI, CT, stereological method, ultrasonic cephalometry).

Method of cephalometry might be widely used as diagnostic, treatment, and research tool by many medical practitioners and anthropologists. Also, by the cephalofacial variables can be counted caphalofacial indexes, which are widely used in anthropology (Rexhepi \& Meka).
The shape of the head and face depend on many factors, such as racial and ethnical affiliation (Enlow, 1982; Morton, 1839; Yokota, 2005), climate, surroundings (Buretic-Tomljanovic et al., 2007; Morton; Radovic et al., 2000), socio-economic (Eder, 1995), nutritional (Shils et al., 2005) and genetic influences (Rexhepi \& Meka). The shape of the cranial base, according to Lieberman (2000a), is a product of phylogenetic, developmental, and functional interactions, whereas the neurobasicranium may influence the growth of upper part of the face (Lieberman, 2000b).

According to Moss \& Young (1960), a functional cranial analysis provides the framework for considering functional and developmental relationships in the cranium. The most serious challenge for the scientists is to explore the latent structure of the studied phenomena, respectively using the underlying dimensions (factors) to explain complex phenomena. The main purpose of this research was to explore the latency of the cephalofacial measurements of female subjects, as well as to facilitate the anthropological

\footnotetext{
* Institute of Sports Anthropology, Prishtina, Kosovo.

** University College "Universi", Pristina, Kosovo.

*** Sport Center for increasing of morpho-functional abilities, Fitness \& Nutrition "Corpore Sano", Pristina, Kosovo.

***** Faculty of Special Education and Rehabilitation, University of Zagreb, Zagreb, Croatia.
} 
explanation of the genetic basis of development of the bones, cartilages and soft tissues of their head, and its morphological construction (Lavelle, 2003).

\section{MATERIAL AND METHOD}

This study is a part of the project "Morphological characteristics of the Kosovo Albanian population" that was carried out at the Institute of Sports Anthropology in Prishtina, Kosovo, and received approval from the Ethics Committee of the University Clinical Center in Prishtina.

According to the International Biological Program have been measured eleven cephalofacial variables. The measurements were done in 193 female subjects of the Kosovo Albanian population, during the period 1997-2002. The examined entities aged 18-35 years of age, were chosen randomly, but always respecting the rule that their psychophysic, dental and soft tissue condition were in normal.

Following the definitions of Martin and Saler all cephalofacial variables were measured by anthropological cephalometer, as well with sliding compass, with accuracy of $1 \mathrm{~mm}$. The following cephalofacial variables were measured:

G-Op (glabela-opistocranium) - head length;

Eu-Eu (eurion-eurion) - head width;

V-Po (vertex-porion) - head height;

$\mathrm{HC}$ - Head circumference;

$\mathrm{N}-\mathrm{Gn}$ (nasion-gnathion) - face height;

Zy-Zy (bizygomatic) - Maximal facial breadth;

Go-Go (gonion-gonion) - bigonial mandibular breadth;

N-Ns (nasion-nasospinale) - Nasal height;

$\mathrm{Al}-\mathrm{Al}$ (alare-alare) - nasal breadth;

LH - lips height;

LW - lips width.

Statistical analysis was performed using SPSS statistical software (version 17.0). All data were analyzed according to basic statistic parameters, correlation analyses and factor analysis.

Factor analysis is used to describe variability among observed (manifest) and correlated variables, to reduce a large number of these variables to a smaller number of latent and uncorrelated factors, as well as to detect and explain the latent structure of observed measured variables. Therefore, by scientists this statistical method is applied as a data reduction or latent structure detection method. A major goal of factor analysis is to represent relationships among sets of variables parsimoniously yet keeping factors meaningful (Ferguson, 1954).

\section{RESULTS AND DISCUSSION}

The results of basic parameters, correlation analyses, and factor analyses are shown in Tables I-V. The complete review of mean values, minimal and maximal values, as well as standard deviations for the total number of study subjects is presented in Table I. The low values of the standard deviation of the mostly all variables indicate that the data points are very close to the average values. Whereas, high value of the standard deviation of the variable Head circumferences (HC) indicates that the data of this variable are spread out over a relatively large range of the average values.

It is real that the morphological types of the current population could not be easy separated, because of the types that interfere with intermediate features.

According to the results of the Table I can be concluded that female subjects are characterized with long, large and medium height head. These results are compatible with the results of other anthropologists who have studied the physical anthropology of the Albanians (Coon; Dhima; Glück, 1897, Ylli).

The results of the correlation matrix (Table II), confirm establishing of some sets of variables, which realize the higher correlations with each other. These relationships between variables within sets involve morpho-genetic, functional and developmental integrations of the cephalofacial variables (Cheverud, 1996).

The next stage before starting with the factor analysis is the evaluation of the Kaiser-Meyer-Olkin measure (KMO) and Bartlett's test.

The Kaiser-Meyer-Olkin (KMO) measure of sampling adequacy tests whether the partial correlations among variables are small, whereas Bartlett's test of sphericity tests whether the correlation matrix is an identity matrix, which would indicate that the factor model is inappropriate. In this way, Bartlett's test of sphericity is used to test the null hypothesis that the variables in the correlation matrix are uncorrelated (Friel, 2007).

To proceed with factor analyses the KMO value should be greater than 0.5. Looking at the Table II, we can see that the KMO measure is 0.602 , what's mean that KMO measure has realized acceptable mediocre value to proceed with further statistical procedures. Also, from the same table, we can see that the Bartlett's test of sphericity is significant with significance level Sig $=0.000$. 
Table I. Basic parameters.

\begin{tabular}{lcccc}
\hline Variables & Minimal & Maximal & Mean & SD \\
\hline G-Op & 164.00 & 200.00 & 180.14 & 6.53 \\
Eu-Eu & 138.00 & 168.00 & 152.61 & 5.72 \\
V-Po & 96.00 & 134.00 & 114.67 & 6.92 \\
HC & 503.00 & 590.00 & 549.70 & 16.91 \\
N-Gn & 97.00 & 132.00 & 112.82 & 5.50 \\
Zy-Zy & 105.00 & 142.00 & 125.36 & 7.40 \\
Go-Go & 89.00 & 124.00 & 103.35 & 5.51 \\
N-Ns & 40.00 & 56.00 & 47.87 & 3.25 \\
Al-Al & 18.00 & 39.00 & 32.67 & 2.33 \\
LH & 10.00 & 25.00 & 16.97 & 2.66 \\
LW & 41.00 & 60.00 & 49.55 & 3.27 \\
\hline
\end{tabular}

Table II. Correlations between variables.

\begin{tabular}{|c|c|c|c|c|c|c|c|c|c|c|c|}
\hline & G-Op & Eu-Eu & V-Po & HC & N-Gn & $Z y-Z y$ & Go-Go & N-Ns & Al-AL & LH & $\mathbf{L W}$ \\
\hline$\overline{\mathrm{G}-\mathrm{Op}}$ & 1.00 & & & & & & & & & & \\
\hline Eu-Eu & $0.32 *$ & 1.00 & & & & & & & & & \\
\hline V-Po & 0.12 & 0.12 & 1.00 & & & & & & & & \\
\hline $\mathrm{HC}$ & $0.49 *$ & $0.34 *$ & $0.45^{*}$ & 1.00 & & & & & & & \\
\hline N-Gn & $0.28 *$ & 0.17 & 0.16 & $0.37 *$ & 1.00 & & & & & & \\
\hline Zy-Zy & -0.02 & 0.05 & $0.29 *$ & $0.53^{*}$ & 0.20 & 1.00 & & & & & \\
\hline Go-Go & $0.24 *$ & $0.42 *$ & 0.10 & $0.26^{*}$ & 0.19 & $0.27 *$ & 1.00 & & & & \\
\hline N-Ns & -0.01 & -0.14 & 0.20 & $0.24^{*}$ & $0.52 *$ & $0.33^{*}$ & 0.04 & 1.00 & & & \\
\hline $\mathrm{A} 1-\mathrm{Al}$ & 0.15 & 0.13 & 0.05 & 0.14 & -0.08 & 0.19 & $0.21 *$ & -0.17 & 1.00 & & \\
\hline $\mathrm{LH}$ & $0.25^{*}$ & 0.16 & 0.03 & 0.07 & $0.32 *$ & -0.17 & 0.00 & 0.07 & -0.06 & 1.00 & \\
\hline LW & 0.19 & 0.16 & -0.29 & -0.09 & 0.09 & -0.19 & $0.24 *$ & -0.03 & $0.25^{*}$ & 0.21 & 1.00 \\
\hline
\end{tabular}

*Correlation is significant at the 0.01 level (2-tailed).

Table III. Kaiser-Meyer-Olkin Measure (KMO) and Bartlett's Test.

\begin{tabular}{lcc}
\hline KMO Measure of Sampling Adequacy & \multicolumn{2}{c}{$\mathbf{0 . 6 0 2}$} \\
\hline \multirow{2}{*}{ Bartlett's Test of Sphericity } & Approx. Chi-Square & 537.29 \\
& df & 55 \\
& Sig. & 0.000 \\
\hline
\end{tabular}

Table IV. Total Variance Explained, communality. Extraction Method: Principal Component Analysis.

\begin{tabular}{lllll}
\hline Component & - & $\%$ of Variance & Cumulative $\%$ & $\mathrm{~h}^{2}$ \\
\hline G-Op & $2.79^{*}$ & $25.34^{*}$ & $25.34^{*}$ & 0.61 \\
Eu-Eu & $1.87^{*}$ & $17.00^{*}$ & $42.34^{*}$ & 0.57 \\
V-Po & $1.53^{*}$ & $13.87^{*}$ & $56.21^{*}$ & 0.59 \\
HC & $1.12^{*}$ & $10.18^{*}$ & $66.39^{*}$ & 0.77 \\
N-Gn & 0.87 & 7.86 & 74.25 & 0.74 \\
Zy-Zy & 0.71 & 6.44 & 80.69 & 0.76 \\
Go-Go & 0.58 & 5.29 & 85.98 & 0.55 \\
N-Ns & 0.51 & 4.62 & 90.60 & 0.81 \\
Al-Al & 0.47 & 4.29 & 94.88 & 0.54 \\
LH & 0.35 & 3.15 & 98.04 & 0.62 \\
LW & 0.22 & 1.97 & 100.00 & 0.75 \\
\hline
\end{tabular}

$1-$ eigenvalue. $\mathrm{h}^{2}-$ communality.* Extracted latent factors.
According to the results of these two statistical measures (Table III), can be concluded the rejection of the null hypothesis - the gained matrix is not an identity matrix, and the fact that the strength of the relationships among measured cephalofacial variables is enough strong to proceed with factor analysis.

The main applications of Factor analysis are to reduce the number of manifest variables and to detect their latent structure in their relationships (Gorsuch, 1983). Therefore, in our research factor analysis is applied as a data reduction or structure detection method (StatSoft) (Darlington, 2004). This mathematic-statistical method is used to study the patterns of relationship among cephalofacial variables that we have measured, with the purpose of discovering about the nature of the latent variables that affect them.

The "optimal" number of the latent factors have been determined using the Kaiser criterion, which suggests to retain those factors with eigenvalues equal or higher than 1 , but always respecting the law of Parsimony, to save and explain, as much as possible, interpretation of the measured manifest variables (Ferguson).

Using the principal component method of Factor Analysis, and applying GutmanKaiser criterion, are extracted four latent factors that explain $66.4 \%$ of total variance (Table IV). The communality of each variable, shown in Table IV, indicates the percentage of variance explained by all the factors jointly. 
For the better explanation of the extracted latent space the main components have been transformed using the Oblimin Rotation Method converged in 37 iterations, with Kaiser Normalization. The number of the iterations indicates that the extracted matrix has medium distribution on the latent space. The explanation of the latent structure of the measured cephalofacial variables has been enabled based on analyzes of three gained matrices:

a) The pattern matrix (Table V) - represents the linear combination of the measured cephalofacial variables. This matrix offers a clearer picture of the relevance of each variable in the factor;

b) The structure matrix (Table V) represents the correlations between the measured cephalofacial variables and latent factors;

c) The component correlation matrix (Table VI) shows the correlations between extracted latent factors;

The similar composition of four extracted latent factors, shown in pattern matrix and structure matrix, indicate clear nature of these factors and their logical interpretation (Table V).

The reciprocal low correlations that latent factors realize with each other (Table VI), ensure us that these factors may stay independently, as well facilitate their interpretation.

\section{CONCLUSION}

The explanation of the latent structure of the cephalofacial variables was enabled by four underlying extracted factors (Tables III-VI).

The data of Table $\mathrm{V}$ indicate that the best projections on the first extracted latent factor, which explain $25.34 \%$ of total variance, have realized variables: head length (G-Op), head breadth (Eu-Eu), and lips height ( $\mathrm{LH})$. This factor, primarily informs about the cranial dimension of the head, so it might be named as the cranial factor.

The best projections on the second extracted latent factor, which explain $17 \%$ of the total variance (Table IV), have realized three cephalofacial variables: head height (VPo), head circumferences (HC), and lips width (LW) (Table V). This factor is assumed to be a latent dimension that informs about neurocranial capacity, and might be named as the factor of intracranial capacity.

The third latent factor, which explains $13.87 \%$ of the total variance (Table IV), contains the best projections that have realized three facial variables: maximal facial breath (Zy-Zy), bigonial mandible breadth (Go-Go), and nasal breadth (Al-Al) (Table V). Because these variables measure

Table V. Pattern Matrix \& Structure Matrix. Extraction Method: Principal Component Analysis. Rotation Method: Oblimin with Kaiser Normalization. Rotation converged in 37 iterations. *The higher projections.

\begin{tabular}{lcccccccc} 
& \multicolumn{4}{c}{ Pattern Matrix } & \multicolumn{4}{c}{ Structure Matrix } \\
\cline { 2 - 9 } & Factor 1 & Factor 2 & Factor 3 & Factor 4 & Factor 1 & Factor 2 & Factor 3 & Factor 4 \\
\hline G-Op & $0.77^{*}$ & -0.07 & -0.03 & 0.01 & $0.77^{*}$ & -0.03 & -0.16 & 0.15 \\
Eu-Eu & $0.69^{*}$ & -0.08 & -0.23 & -0.18 & $0.69^{*}$ & -0.04 & -0.35 & -0.04 \\
V-Po & 0.25 & $-0.72^{*}$ & 0.00 & 0.08 & 0.22 & $-0.72^{*}$ & -0.12 & 0.23 \\
HC & 0.47 & $-0.52^{*}$ & -0.28 & 0.26 & 0.53 & $-0.57^{*}$ & -0.42 & 0.43 \\
N-Gn & 0.27 & 0.06 & 0.07 & $0.78^{*}$ & 0.40 & -0.03 & 0.01 & $0.82^{*}$ \\
Zy-Zy & -0.23 & -0.40 & $-0.58^{*}$ & 0.41 & -0.09 & -0.54 & $-0.59^{*}$ & 0.44 \\
Go-Go & 0.27 & 0.13 & $-0.63^{*}$ & 0.13 & 0.40 & 0.06 & $-0.66^{*}$ & 0.17 \\
N-Ns & -0.26 & -0.03 & 0.01 & $0.90^{*}$ & -0.10 & -0.18 & 0.02 & $0.86^{*}$ \\
Al-Al & 0.05 & 0.16 & $-0.70^{*}$ & -0.17 & 0.15 & 0.12 & $-0.69^{*}$ & -0.17 \\
LH & $0.57^{*}$ & 0.23 & 0.43 & 0.25 & $0.56^{*}$ & 0.27 & 0.36 & 0.30 \\
LW & 0.19 & $0.80^{*}$ & -0.31 & 0.16 & 0.31 & $0.75^{*}$ & -0.26 & 0.08 \\
\hline
\end{tabular}

\begin{tabular}{lcccc}
\hline Factors & $\mathbf{1}$ & $\mathbf{2}$ & $\mathbf{3}$ & $\mathbf{4}$ \\
\hline 1 & 1.00 & & & \\
2 & 0.06 & 1.00 & & \\
3 & -0.16 & 0.11 & 1.00 & \\
4 & 0.17 & -0.15 & -0.03 & 1.00 \\
\hline
\end{tabular}

Table VI. Component Correlation Matrix. Extraction Method: Principal Component Analysis. Rotation Method: Oblimin with Kaiser Normalization. 
the transversal dimension of the face the extracted factor might be known as the transversal factor of the face.

On the fourth latent factor, which explains $10.18 \%$ of the total variance (Table IV), the best projections have realized two other facial variables: face height $(\mathrm{N}-\mathrm{Gn})$ and nasal height (N-Ns), which seems to present the longitudinal dimension of the face (Table V). This factor might be known as the longitudinal factor of the face.
Reduction of multiple measured variables in a small number of latent factors may help and facilitate the work of anthropology in studying and explaining of the morphological construction, and genetically development of the bones, cartilages and soft tissues of the female's head. The composition of the extracted factors is compatible with the anthropological explanation of the anthropologists regarding the development of these tissues of the head.

REXHEPI, A. M. \& BRESTOVCI, B. Latencia de variables cefalofaciales en mujeres. Int. J. Morphol., 31(2):765-770, 2013

RESUMEN: Los huesos craneofaciales humanos son sin duda la parte más importante del cuerpo, así como las bases para los tejidos blandos de la cara y el cráneo. Esta parte del cuerpo es una estructura extremadamente compleja, que tiene un número importante de funciones tales como alimentación, sensorial, protección y comunicación. El objetivo principal de esta investigación fue estudiar y explicar las estructuras latentes de mediciones cefalofaciales en mujeres. En 193 mujeres, con edades entre 18-35 años, se realizaron 11 mediciones cefalofaciales. Los datos recogidos se analizaron a través de parámetros descriptivos, análisis de correlación y análisis factorial. De acuerdo con los resultados los parámetros básicos de las mujeres estudiadas se caracterizaron con alturas de cabeza largas, grandes y medianas. El análisis de correlación confirma algunos conjuntos de variables que señalan las correlaciones más altas entre sí. De acuerdo con el análisis de componentes principales del análisis factorial, con el método de rotación directa de oblimin, y utilizando el criterio de Keiser se extrajeron cuatro factores latentes que explican el 66,39\% de la varianza total: factor craneal, factor de capacidad intracraneal, factor transversal de la cara y factor longitudinal de la cara. La composición de los factores extraídos es compatible con la explicación antropológica respecto al desarrollo de estos tejidos de la cabeza.

PALABRAS CLAVE: Medidas cefalofaciales; Estructura latente; Explicación antropológica.

\section{REFERENCES}

Buretic-Tomljanovic, A.; Giacometti, J.; Ostojic, S. \& Kapovic, M. Sex specific differences of craniofacial traits in Croatia: The impact of environment in a small geographic area. Ann. Hum. Biol., 34(3):296-314, 2007.

Coon, C. S. The races of Europe. $2^{\text {nd }}$ ed. New York, Macmillan, 1939. p.293.

Cheverud, J. M. Developmental integration and the evolution of pleiotropy. Am. Zool. 36:44-50, 1996.

Darlington, R. B. Factor Analysis. 2004. Available in: http:// comp9.psych.cornell.edu/Darlington/factor.htm

Dhima, A. Gjurmime antropologjike per shqiptaret (Anthropological surveys on the Albanians). Tirana, Akademia e Shkencave e RPS T, 1985. pp.28-9, 106-12, 1268 .

Eder, R. A. Craniofacial anomalies: Psychological perspectives. New York, Springer-Verlag, 1995. pp.68-71.

Enlow, D. H. The Human Face: An Account of the Postnatal Growth and Development of the Craniofacial Skeleton. New York, Harper and Row, 1968.
Enlow, D. H.; Pfister, C.; Righardson, E. \& Kuroda, T. An Analysis of Black and Caucasian Craniofacial Patterns. Angle Orthod., 52(4):281-7, 1982.

Ferguson, G. A. The concept of Parsimony in factor analysis. Psychometrika, 19(4):281-290, 1954.

Friel, C. M. Notes on Factor Analysis. Criminal Justice Center, Sam Houston State University, 2007. Available in: http:// www.bama.ua.edu/ jcsenkbeil/gy523/Factor\%20Analysis.pdf

Glück, L. Zur physischen anthropologie der Albanesen. Wissenschaften und Mitteilungen aus Bosnien und der Hercegovina. 5:365-402, 1897.

Gorsuch, R. L. Factor Analysis. Hillsdale, New Jersey, Erlbaum Assoc Inc., 1983.

Lavelle, C. Development and anatomy relevant to the head, neck, and orofacial tissues. Cranofacial development, 2003. Available in: http://fds.oup.com/www.oup.com/pdf/13/ 9780198510963.pdf

Lieberman, D. E.; Ross, C. F. \& Ravosa, M. J. The primate cranial base: ontogeny, function, and integration. Am. J. Phys. Anthropol., Suppl. 31:117-69, 2000a. 
Lieberman, D. E.; Pearson, O. M. \& Mowbray, K. M. Basicranial influence on overall cranial shape. J. Hum. Evol., 38(2):291$315,2000 b$.

Martin, R.; Ober, W.; Garrison, C.; Welch, K. \& Hutchings, R. T. Fundamentals of Anatomy and Physiology. $5^{\text {th }}$ ed. New Jersey, Prentice Hall, 2001. p.195.

Morton, S. G. Crania Americana; or a comparitive view of the skulls of various aboriginal nations of North and South America: to which is prefixed an essay on the varieties of the human species. Philadelphia, J. Dobson, 1839.

Moss, M. L. \& Young, R. W. A functional approach to craniology. Am. J. Phys. Anthrop., 18:281-92, 1960.

Radovic, Z.; Muretic, Z.; Nemirovskij, V. \& Coklica, V. G. Craniofacial Variations in a South Dalmatian Population. Acta Stomatol. Croat., 34(4):399-403, 2000.

Rexhepi, A. \& Meka, V. Cephalofacial morphological characteristics of Albanian Kosova population. Int. J. Morphol., 26(4):935-40, 2008

Shils, M. E.; Shike, M.; Ross, A. K.; Caballero, B. \& Cousins, R. J. Modern nutrition in health and disease: Role of nutrition in craniofacialand oral tissue development. $10^{\text {th }}$ ed. Baltimore, Lippincott Williams \& Wilkins, 2005. pp.1155-67.

Williams, P. L.; Bannister, L. H.; Berry, M. M.; Collins, P.; Dyson, M.; Dussek, J. E.; et al. Gray's Anatomy. $38^{\text {th }}$ ed. London, Churchill Livingstone, 1995. p.612.

Ylli, A. Disa të dhëna kraniometrike (Some craniometric data) (in Albanian). Tirana, Akademia e Shkencave e RPS T, 1975. pp.64-97.

Yokota, M. Head and facial anthropometry of mixed-race US Army male soldiers for military design and sizing: a pilot study. Appl. Ergon., 36(3):379-83, 2005.
Correspondence to:

Agron M. Rexhepi

Str. "Sali Butka" Nr.31/D

10000 Prishtina

KOSOVO

Phone: +377 44110855

Email: agronmrexhepi@gmail.com

Received: 07-03-2012

Accepted: 25-02-2013

Email. agronmrexhepi@gmail.com 